\title{
THE USE OF ASSESSMENT FOR LEARNING IN PHYSICAL EDUCATION CLASSES: PRESERVICE TEACHERS' PERCEPTIONS
}

O uso da avaliação para a aprendizagem nas aulas de Educação Física: Perceções de estudantes estagiários

El uso de la evaluación para el aprendizaje en las clases de Educación Física:

Percepciones de estudiantes en prácticas

\author{
Paula Fazendeiro Batista (1)
}

\section{André Pisco de Moura (2)}

Financial support: The work of the second author is supported by Fundação para a Ciência e Tecnologia (FCT). PhD grant: SFRH/BD/137848/2018

Acknowledgments: We would like to acknowledge the investment of the time of every preservice teacher and their contribute to this study.

(1) University of Porto, Faculty of Sport, Portugal. Research Center of Education, Innovation and Intervention in Sport (CIFI2D) Phone: +351 966342447. Email: paulabatista@,fade.up.pt

(2) University of Porto, Faculty of Sport, Portugal. Phone: +351917522 046. Email: luisandrepmoura@hotmail.com

\section{Abstract}

Assessment is not a consensual topic among teachers, and several are the challenges it poses, especially to those in training. Among the different assessment perspectives, the use of it as a means of promoting learning has been gaining ground. This paper aims to capture the understandings, advantages, and problems that preservice teachers faced during the implementation of Assessment for Learning (AfL) in Physical Education classes during their school placement. Semi-structured interviews were carried out with four preservice teachers, chosen to participate in this study. Using a thematic analysis, three categories were defined: 1) understanding about AfL; 2) experience of preparing and implementing AfL, and 3) impact of this experience on their future as a teacher. Preservice teachers seem to have a similar understanding of AfL. They reported that planning is demanding but impacted positively on students' motivation and participation. This experience changed their way of preparing classes to a studentcentered approach.

Keywords: Physical Education; assessment for learning; preservice teachers' perceptions 


\section{Resumo}

A avaliação não é um tópico consensual entre professores e vários são os desafios que coloca, especialmente aos que estão em formação. De entre as correntes da avaliação, o seu uso como um meio de promover aprendizagem tem ganho consenso. Este trabalho pretende capturar os entendimentos, vantagens e problemas que estudantes-estagiários encontraram durante a implementação dos processos da avaliação para a aprendizagem (AfL) em aulas de Educação Física durante o seu estágio profissional. Entrevistas semiestruturadas foram realizadas a quatro estudantes-estagiários, selecionados intencionalmente para participarem neste estudo. Recorrendo à análise temática, três categorias foram definidas: 1) entendimentos sobre a AfL; 2) experiência de preparação e implementação da AfL; e 3) impacto desta experiência no seu futuro como professor/a. Os estudantes-estagiários parecem ter um entendimento similar sobre a AfL. Eles referiram que o planeamento é extremamente exigente, mas que influenciou positivamente os níveis de motivação e participação dos alunos. Esta experiência fê-los alterar a forma de preparar as aulas no sentido de centrarem o ensino no aluno.

Palavras-chave: Educação Física; avaliação para a aprendizagem; perceções de estudantes estagiários

\section{Resumen}

La evaluación no es un tema consensuado entre los profesores y plantea una serie de retos, especialmente para los que están en formación. Entre las corrientes de evaluación, su uso como medio para promover el aprendizaje ha ganado terreno. Este trabajo busca capturar los entendimientos, ventajas y problemas que los estudiantes de la formación inicial del profesorado (FIP) encontraron durante la implementación de la evaluación para el aprendizaje (AfL) en las clases de Educación Física durante sus prácticas. Se realizaron entrevistas semiestructuradas a cuatro estudiantes en prácticas, seleccionados intencionalmente para participar en este estudio. Utilizando un análisis temático, se definieron tres categorías: 1) comprensión de la AfL; 2) experiencia de preparación e implementación de la Afl y 3) impacto de esta experiencia en su futuro como profesor/a. Estos estudiantes parecen tener una comprensión similar de la AfL. Señalaron la planificación como extremadamente exigente, pero con una influencia positiva en la motivación y participación de los/as alumnos/as. Después de esta experiencia, 
cambiaran la manera de preparar las lecciones hacia una enseñanza enfocada en los alumnos/as.

Palabras clave: Educación Física; evaluación para el aprendizaje; percepciones de profesores en prácticas

\section{Introduction and contextualization}

Assessment is essential in all educational levels. For teachers, it seems to be a complex and challenging issue (López-Pastor, Kirk, Lorente-Catalán, Macphail, \& Macdonald, 2012). These challenges are even more pronounced at teachers' training context.

There is a growing consensus that the chief role of assessment should be to promote learning (Black \& Wiliam, 1998; Klenowski, 2009; MacPhail, Halbert, \& O’Neill, 2018), but teachers still facing a lot of problems to change their practices and for the preservice teachers (PSTs) when they come to the school placement the difficulties seem to be the biggest. Attending to this framework and the necessity to help PSTs to deal better with assessment, the purpose of this work was to capture the understandings, advantages, and problems that PSTs faced during the implementation of Assessment for Learning (AfL) in Physical Education classes at their school placement.

\section{Study design}

The study took place during the school placement (second year of Master of Teaching in Physical Education on Basic and Secondary Education) of four PSTs from the University of Porto, Faculty of Sport at the academic year 2018/19.

The school placement takes place in a cooperating school during 10 months in groups of 3/4 PSTs supervised by a teacher from school and a university professor. Each preservice teacher is responsible for one of the cooperating teachers' classes during the whole year and shares another one with their colleagues.

PSTs from two cooperating schools were purposively selected (Patton, 2002), according to their personal characteristics and interest to participate in this work.

PSTs, after sign the informed consent, were interviewed by the first author at the final of his/her implementation of AfL.

Interviews were verbatim transcripted and analysed through thematic analysis. Data were organized into three categories: 1) understanding about AfL; 2) experience of 
preparing and implementing AfL processes, and 3) impact of this experience on their future as a teacher.

\section{Results}

Preservice teachers seem to have a common understanding of AfL. They believe that this method of assessment intends to improve students' learning, which occurs through students' active participation in assessment processes, as self, peer, and co-assessment:

"AfL is shared with students because they interact and give their opinion. We (teachers) help them to understand which level they are and what they can do to improve" (PST1-ref1).

"Students had to fulfil at the end of each class the difficulties they faced during that class and how they can contribute to their colleagues. At the next class, they knew in what they have to work on" (PST4-ref1).

Furthermore, PSTs identified that in AfL the educational aim, that is defined by the teacher, is a guide for all the process, helping the students to work in order to achieve it. This process is shared with students and continually developed along the unit through the class goals that contribute to the final objective:

"AfL means work during a process to a goal, which is defined at the beginning" (PST3-ref1).

About PSTs' experience of implementing and using AfL in their classes, they reported that planning is demanding and difficult and demands hard-work and time investment. They also referred that this phase is essential to the success of implementation and their previous lack of knowledge was the main challenge they faced.

"The process of preparation is very complicated, arduous and costly much time, but I think this also happened due to my lack of background. I just learned and had to implement it, and then there was no time to mature ideas. In the beginning, I faced many problems, but the results pay off the investment because the work was organized since the first moment" (PST3-ref2).

PSTs faced other problems such as the definition of partial goals for each class; however, they say that working together with their students helped them to improve it:

"Define the goals and then to achieve it during the class was very hard" (PST2-ref1).

"This model helped a lot of students to understand what they were doing, and they appreciated that" (PST3-ref3).

Initially, students also struggled with several problems related to self and peer assessment. They could attribute a score but cannot justify it.

"It was very hard to stimulate students to think, reflect, be critical and help their colleagues because they had no idea of what they should write. So, we created signs with scores and students use that and then justified their classification" (PST4-ref2). 
The main disadvantage pointed by one PST was the fact that in AfL students are aware of everything teachers do which give them the power to question the teacher:

"The biggest problem is that students know everything that occurs. The more aware students are the more chances they have to make questions about their grades" (PST3-ref4).

PSTs reported that this experience had a positive impact and provided learning in duplicate because both students and teachers learned. They considered that students were more involved (cognitively), motivated and interested during the classes and the communication between teachers and students was bidirectional:

"Teacher is not the only one who speaks. Students become capable of explaining/argue, they involve themselves and subsequently learn much more. Additionally, we also learn from them" (PST3-ref5).

"Students learn more because they have to understand it cognitively. If they do not go for it, they cannot achieve their goals. When it is conducted by teachers, students listen, understand and do it, but do not realize more than the 'doing"' (PST4-ref3).

PSTs identified that AfL allowed them to change their teaching conception. They pass to give voice to students, act as a facilitator and develop a student-centered approach:

"My intervention was adapted to students' needs, to what they say and do" (PST2-ref2).

\section{Conclusions}

PSTs identified AfL as a very enriching experience on their teacher training that allows the improvement of their teaching and their students' learning, motivation, and interest. They started placing their students as the center of the learning process, acting according to their needs, including assessment in the teaching-learning process and sharing goals and assessment criteria with them. PSTs start giving more importance to the explanation of the purpose behind students' work, considering students' evolution in assessment and develop processes of shared assessment. Although all the PSTs consider that the planning process is very demanding, they strongly recommend it to other professionals.

\section{References}

Black, P., \& Wiliam, D. (1998). Inside the black box: Raising standards through classroom assessment. Phi Delta Kappan, 80(2), 139-148.

Klenowski, V. (2009). Assessment for learning revisited: An Asia-Pacific perspective. Assessment in Education: Principles, Policy, and Practice, 16(3), 263-268. 
López-Pastor, V. M., Kirk, D., Lorente-Catalán, E., Macphail, A., \& Macdonald, D. (2012). Alternative assessment in physical education: A review of international literature. Sport Education and Society. doi:10.1080/13573322.2012.713860

MacPhail, A., Halbert, J., \& O’Neill, H. (2018). The development of assessment policy in Ireland: the story of the junior cycle reform. Assessment in Education: Principles, Policy \& Practice. doi:10.1080/0969594X.2018.1441125

Patton, M. Q. (2002). Qualitative Research and Evaluation Methods (3rd ed.). California: Sage Publications. 